\title{
Puerarin Restrains the Malignant Progression of Ovarian Cancer Cells via Regulating P53 and PTEN expressions
}

Fu-le He ( $\sim$ hefule@163.com )

Zhejiang Chinese Medical University https://orcid.org/0000-0001-9010-0600

\section{Mei-lan Hu}

Zhejiang universit

\section{Tian-yin Ruan}

Zhejiang Chinese Medical University

\section{Hao Li}

Zhejiang Chinese Medical University

Jiao-yi Pan

Zhejiang Chinese Medical University https://orcid.org/0000-0001-7723-484X

\section{Zhen-yu-tong Du}

Zhejiang Chinese Medical University

\section{Kai-han Wu}

Zhejiang Chinese Medical University

\section{Yong-ju Ye}

Lishui Hospital of Traditional Chinese Medicine

Fu-le He

Zhejiang Chinese Medical University

\section{Research Article}

Keywords: puerarin, ovarian cancer, P53, phosphatase and tensin homolog

Posted Date: September 9th, 2021

DOl: https://doi.org/10.21203/rs.3.rs-669724/v1

License: (c) (i) This work is licensed under a Creative Commons Attribution 4.0 International License.

Read Full License 


\section{Abstract}

Objective: Puerarin has been proven to treat diverse cancers, but its function on ovarian cancer $(\mathrm{OC})$ is still blurry and needs further research.

Methods: After OC cells were treated with $10,20,40,80$, or $160 \mu \mathrm{g} / \mathrm{mL}$ pue, cell vitality, colony number, apoptosis, the positive expression of P53, migration, and invasion were examined by cell function experiments, TUNEL staining, and immunofluorescence. P53, P21, PTEN, FGF1, GLI2, and ERK1/2-NF-KB pathway-related marker expressions were examined by western blot.

Results: Pue weakened the OC cell vitality, colony number, and the positive expression of P53 but enhanced apoptosis in a dose-dependent manner. Next, we discovered that pue enhanced the P53, P21, PTEN, and GLI2 levels but restrained the FGF1 level. Pue also alleviated the OC cell migration and invasion activity. We also confirmed that pue weakened the ERK1/2-NF-KB pathway-related marker expressions.

Conclusion: Puerarin restrained the OC progression via modulating P53 and PTEN expressions.

\section{Introduction}

The mortality rate of ovarian cancer $(\mathrm{OC})$ ranks first among malignant tumors of the female genital tract, and it is the main tumor that threatens women's health and lives [1]. Among them, hormones, smoking, diet, and family history are the risk factors for OC [2].. Because the ovary is located at the bottom of the pelvic cavity, the lesion is not easy to be found, its early symptoms are not obvious, and the clinical lack of effective screening and diagnosis methods, $70 \%$ of OC patients have entered the advanced stage when diagnosed [3].Currently, the treatment of $\mathrm{OC}$ is still based on surgery, supplemented by chemotherapy and radiation therapy, but the 5 -year survival rate of OC is only about $30 \%$ [4]. Therefore, it is of great significance to research the mechanism of $\mathrm{OC}$ and explore new therapeutic targets.

Estrogen exerts a crucial role in the presence and development of $\mathrm{OC}$ through the signal transduction pathway mediated by estrogen receptors [5]. Clinical case-control researches have exhibited that longterm estrogen replacement therapy (ERT) might increase the risk of OC[6]. Ingram et al. investigated 44241 women and confirmed that ERT enhanced the risk of OC, and pointed out that this risk was related to the time of using ERT [7]. However, it is curious that phytoestrogens, which are similar in structure to estrogen, have a certain degree of anti-cancer effect. A large number of pieces of evidence have illustrated that phytoestrogens have biological effects such as anti-proliferation, anti-oxidation, inducing cell apoptosis, and regulating immunity. [8]. At present, phytoestrogens have received extensive attention in the prevention and treatment of sex hormone-related tumors. In vitro experiments have exhibited that phytoestrogens have inhibitory effects on diverse cancer cells, including breast cancer, ovarian cancer, gastric cancer, and colon cancer $[9,10]$. 
For a long time, the phytoestrogens contained in Chinese medicines and compound prescriptions have exerted a pivotal role in the treatment of gynecological diseases and women's health care. Pueraria lobata is the dried root of the legume Pueraria lobata (Willd.) Ohwi or Pueraria thomsonii Benth. Puerarin (Pue) is a monomer extracted from Pueraria lobata. As a kind of phytoestrogens, it has a wide range of pharmacological activities such as vasodilation, anti-oxidation, anti-cancer, anti-inflammatory, and reducing insulin resistance [11-15]. Effective evidence has been obtained for the treatment of endometriosis with pue, suggesting that pue may have a good anti-proliferative ability[16, 17] .However, the existing treatments are still very few and simple to explore the mechanism of the relationship between OC cell proliferation, changes in apoptosis, and pue.

In order to study the possible inhibitory effect of pue on OC cells and its mechanism, we took human OC cells SKOV3 and rat OC cells Nutu-19 as the research objects to detect the inhibitory effect of pue on OC cells and its molecular mechanism.

\section{Methods}

\section{Cell lines}

Human OC cell line (SKOV3, MXC349) and rat OC cell line (Nutu-19, MXC290) were obtained from MEIXUAN (China) and grown in RPMI1640 medium (SH30809.01, Hyclone, USA) augmented with 10\% fetal bovine serum (FBS, 11011-8615, Tianhang, China), and then placed in a cell incubator (BB150, Thermo Fisher Scientific, USA).

\section{Cell processing}

In this research, puerarin (82435, Sigma-Aldrich, USA) was dissolved in methanol and diluted in RPMI1640 medium without FBS to a dilution of $0,10,20,40,80$, and $160 \mu \mathrm{g} / \mathrm{mL}$. Next, we used the diluted puerarin to treat cells for 24 hours $(\mathrm{h})$ or $48 \mathrm{~h}$.

\section{Cell viability assay}

Trypsin-digested cells $\left(1 \times 10^{4}\right.$ cells $\left./ \mathrm{mL}\right)$ were transferred to the cell incubator for culture. After $24 \mathrm{~h}$, cells were reacted with $0,10,20,40,80$, and $160 \mu \mathrm{g} / \mathrm{mL}$ puerarin for 24 or $48 \mathrm{~h}$. Thereafter, we used $10 \mu \mathrm{L} \mathrm{CCK}$ 8 solution (HY-K0301, MCE, USA) to stimulate cells for $4 \mathrm{~h}$ at the cell incubator. In the end, we used a microplate reader (CMaxPlus, Molecular Devices, USA) to compare the absorbance at $450 \mathrm{~nm}$.

\section{Cell colony-forming experiment}

The well-growing logarithmic growth phase cells were digested and re-suspended in RPMI1640 containing $10 \%$ FBS. After cells $\left(1 \times 10^{3}\right)$ were seeded into a 6 -well plate, they were dealt with accordingly. After incubation for 14 days, we used $75 \%$ alcohol (A171299, Aladdin, China) to fix cells for $1 \mathrm{~h}$ at $4{ }^{\circ} \mathrm{C}$. After washing with phosphate-buffered saline (PBS, SH30256.01, Hyclone, USA), they were stained with 
Giemsa dye solution (548-62-9, Qiangshun, China) for 2 minutes (min). Finally, we used a microscope (AE2000, Motic, Germany) to count the colony number.

\section{TUNEL}

We used a TUNEL apoptosis kit (C1090, Beyotime, China) to examine apoptosis. First, cells $\left(1 \times 10^{4}\right)$ were inoculated in a 6 -well plate containing a cover glass until the confluence reached $80 \%$. After cells were treated based on the above cell process, we used $4 \%$ paraformaldehyde (P0099, Beyotime, China) to fix cells for 10 min. After washing, we used 0.5\% Triton X-100 (P1080, Solarbio, China) to permeate cells for 2 min and washed the cells with PBS for 3 times. Next, cells were reacted with TUNEL test solution (C1090, Beyotime, China) for $1 \mathrm{~h}$ at $37^{\circ} \mathrm{C}$. After washing, we used DAPI (ab228549, Abcam, UK) to stain the nucleus. After cells were sealed with mounting media (S2100, Solarbio, China), we used a fluorescence microscope (AE31E, Motic, Germany) to observe the results.

\section{Immunofluorescence}

Cells $\left(1 \times 10^{4}\right)$ were treated based on the above cell process. After cells were fixed and permeated, they were blocked with $3 \%$ BSA. Next, cells were reacted with anti-p53 antibody (1:400, AF0879, Affinity, USA) for $1 \mathrm{~h}$ at $37^{\circ} \mathrm{C}$ followed by the addition of anti-rabbit IgG H\&L (1:1000, ab150077, abcam, UK) for $0.5 \mathrm{~h}$ at $37^{\circ} \mathrm{C}$. Thereafter, we used DAPI to stain the nucleus. After washing, they were sealed with mounting media and then observed with the fluorescence microscope.

\section{Western blot}

The puerarin-treated cells were routinely harvested and lysed on ice for 30 min using cell lysis buffer (P0013D, Beyotime, China). After centrifugation, the cell lysate was harvested and the protein concentration in each group was examined via BCA kit (pc0020, Solarbio, China). After denaturation, the samples were subjected to protein electrophoresis and transferred to a PVDF membrane (10600023, GE Healthcare Life, USA). After blocking, they were reacted with primary antibody overnight at $4^{\circ} \mathrm{C}$ followed by the addition of secondary antibody (S0001, Affinity, USA) for $1 \mathrm{~h}$ at $37^{\circ} \mathrm{C}$. Finally, the blots were developed with a color reagent (1705061, BIO-RAD, USA) in a chemic luminous instrument (610020-9Q, Clinx, China). The primary antibodies of anti-p53 antibody (1:2000), anti-p21 antibody (1:2000, AF6290), anti-PTEN antibody (1:2000, AF6351), anti-GLI2 antibody (1:3000, DF7541), anti-phospho-NF-kB p65 (Ser536) antibody (1:2000, AF2006), anti-NF-kB p65 antibody (1:2000, AF5006), anti-phospho-IKBa (Ser32/Ser36) antibody (1:2000, AF2002), anti-IKBa antibody (1:1000, AF5002), anti-phospho-ERK1/2 (Thr202) antibody (1:1000, AF3240), anti-ERK1/2 antibody (1:5000, AF0155), and GAPDH (1:20000, AF7021) were bought from Affinity (USA). Anti-FGF1 antibody (1:1000, ab207321) was bought from Abcam (UK).

\section{Wound healing assay}


First, we used a marker pen to draw horizontal lines evenly on the back of the 6-well plate. Next, the puerarin-treated cells $\left(5 \times 10^{5}\right)$ were added into each well and placed in the cell incubator for $24 \mathrm{~h}$. The next day, we used a $200 \mu \mathrm{L}$ pipette tip to make a perpendicular scratch on the horizontal lines. The floating cells were washed by PBS and RPMI 1640 medium without FBS was added into each well for culture. Samples were taken at 0 h, 24 h, and $48 \mathrm{~h}$ and photographed with the microscope.

\section{Cell migration and invasion assay}

Cells $\left(5 \times 10^{5}\right)$ were treated based on the above cell process. For cell migration, a Transwell chamber (3422, Corning, USA) was placed in the 24 well plates. For cell invasion, we used RPMI 1640 medium to dilute Matrigel (356234, BDBiosciences, USA), which was uniformly coated in the Transwell chamber and incubated overnight at $4^{\circ} \mathrm{C}$. For migration (invasion), the upper chamber was injected into $200 \mu \mathrm{L}$ cell suspension without FBS and the lower chamber was injected into $600 \mu \mathrm{L}$ RPMI 1640 medium augmented with $10 \%$ FBS and then placed in the cell incubator for $24 \mathrm{~h}$. Thereafter, we used cotton swabs to wipe off the cells at the bottom of the upper chamber and fix them with $4 \%$ paraformaldehyde for $10 \mathrm{~min}$. After washing, we used a $0.1 \%$ crystal violet dye solution (548-62-9, Qiangshun, China) to fix cells for 30 min. Finally, the migrated and invaded cells were photographed and counted via the microscope.

\section{Statistical analysis}

The statistical analysis was carried out by SPSS software (16.0, IBM, USA). One-way ANOVA was employed for comparing the differences among multiple groups. SNK analysis was employed for comparison between groups. Kruskal-Wallis $\mathrm{H}$ test was employed for those with uneven variance. The data were expressed as mean \pm standard deviation. $P<0.05$ was designated as statistically significant.

\section{Results}

\section{Pue weakened the $\mathrm{OC}$ cell vitality and colony number in a dose-dependent manner}

The chemical structure of pue was displayed in Fig. 1a. Cell vitality assay clarified that after cells were reacted with $10,20,40,80$, or $160 \mu \mathrm{g} / \mathrm{mL}$ pue for $24 \mathrm{~h}$ or $48 \mathrm{~h}$, cell vitality was obviously attenuated until pue' concentration reached $40 \mu \mathrm{g} / \mathrm{mL}$ (Fig. 1b, $\mathrm{P}<0.05$ ), thus we chose 40, 80, and $160 \mu \mathrm{g} / \mathrm{mL}$ pue for subsequent experiments. Since cell vitality was lower in cells treated with pue for $48 \mathrm{~h}$ than cells treated with pue for $24 \mathrm{~h}, \mathrm{OC}$ cells were treated with pue at the specified time ( $48 \mathrm{~h})$ for subsequent experiments. Next, we also discovered that 80 and $160 \mu \mathrm{g} / \mathrm{mL}$ pue obviously restrained the colony number of OC cells (Fig. 2, $\mathrm{P}<0.05)$.

\section{Pue enhanced apoptosis and blunted the positive expression of P53 in OC cells}

In Fig. 3a-3b, TUNEL staining manifested that different concentrations' pue extremely enhanced apoptosis $(P<0.01)$. Immunofluorescence assay manifested that $40 \mu \mathrm{g} / \mathrm{mL}$ pue slightly weakened the 
positive expression of $P 53$, while 80 and $160 \mu \mathrm{g} / \mathrm{mL}$ pue evidently weakened the positive expression of P53 (4a-4b, $P<0.05)$.

\section{Pue enhanced the P53, P21, PTEN, and GLI2 levels but restrained the FGF1 level}

As displayed in Fig. 5a-5b, 40, 80, and $160 \mu \mathrm{g} / \mathrm{mL}$ pue greatly elevated the P53 and P21 levels of SKOV3 and NuTu-19 cells $(P<0.05)$. Meanwhile, the PTEN level was intensified in SKOV3 cells treated with 80 and $160 \mu \mathrm{g} / \mathrm{mL}$ pue, and the PTEN level was intensified in NuTu-19 cells treated with 40, 80 and 160 $\mu \mathrm{g} / \mathrm{mL}$ pue (Fig. 5a-5b, $\mathrm{P}<0.05$ ). The FGF1 level was weakened in SKOV3 and NuTu-19 cells treated with $160 \mu \mathrm{g} / \mathrm{mL}$ pue (Fig. 5a-5b, $\mathrm{P}<0.05$ ). However, the GLI2 level has no obvious change after different concentrations' pue treatment.

\section{Pue Alleviated The Oc Cell Migration And Invasion}

To check the role of pue on migration and invasion of $\mathrm{OC}$ cells, we conducted the wound healing and Transwell assay. As could be seen, 80 and $160 \mu \mathrm{g} / \mathrm{mL}$ pue evidently attenuated the migration of SKOV3 and NuTu-19 cells in a time dependent manner, meanwhile, the migration of NuTu-19 cells treated with 40 $\mu \mathrm{g} / \mathrm{mL}$ pue for $48 \mathrm{~h}$ was obviously blunted (Fig. 6a-6b, $\mathrm{P}<0.05$ ). Transwell assay clarified that $40 \mu \mathrm{g} / \mathrm{mL}$ pue obviously alleviated the NuTu-19 cell migration and SKOV3 cell invasion, meanwhile, 80 and 160 $\mu \mathrm{g} / \mathrm{mL}$ pue greatly attenuated the migration and invasion of SKOV3 and NuTu-19 cells (Fig. 7a-7b, $\mathrm{P}<$ 0.05).

\section{Pue Weakened The Erk1/2-nf-kb Pathway-related Marker Expressions}

As exhibited in Fig. 8a-8b, 80 and $160 \mu \mathrm{g} / \mathrm{mL}$ pue strongly alleviated the ratios of p-NF-KBp65/NF-KBp65, $\mathrm{p}-\mathrm{lkBa} / \mathrm{lkBa}$, and $\mathrm{p}$-ERK1/2/ERK1/2, meanwhile, $40 \mu \mathrm{g} / \mathrm{mL}$ pue also attenuated the ratios of $\mathrm{p}-\mathrm{NF}$ KBp65/NF-KBp65 and p-ERK1/2/ERK1/2 $(P<0.05)$.

\section{Discussion}

In recent years, botanic and natural drugs are a valuable resource for the development of new anti-cancer drugs because of their advantages of multi-targets, multi-links, small side effects, and lasting curative effects $[18,19]$. One research clarified that pue intervention evidently restrained the colon cancer cell proliferation, enhanced apoptosis, and Bax expression [20]. Another research manifested that pue blunted the p-Akt and Bcl-2 expressions but enhanced the Bax expression, thereby exerting an anti-glioblastoma effect [21]. Hu et al. exhibited that pue restrained the growth of non-small cell lung cancer by inducing apoptosis and autophagy [13]. In our research, we supplemented the deficiencies of pue in OC research. Our results exhibited that pue attenuated the viability, proliferation, migration, and invasion of $\mathrm{OC}$ cells but promoted apoptosis in a time-dependent and dose-dependent manner, which was consistent with the experimental results of Ye et al. in bladder cancer cells [22]. 
The initiation of $\mathrm{OC}$ is a relatively complex process involving multiple genes and is closely correlated with the abnormal expression of multiple tumor suppressor genes. The P53 gene is located on chromosome 17p13.1, and mainly contains 11 exons with a total length of $20 \mathrm{~kb}$ [23]. P53 gene is a tumor suppressor gene that has the highest correlation with human tumors, and its mutation or deletion is the cause of many tumors [24]. P53 controls cell cycle progression by transactivating key downstream molecules (p21) [25]. Moreover, the activation of P53 up-regulates the transcription of PTEN, thereby enhancing its expression [26]. In 1997, Steck et al. discovered a tumor suppressor gene at the 10q23 site of a variety of tumor chromosomes, named PTEN [27]. The protein encoded by PTEN exhibited dual-specific phosphatase activity and had the characteristics of phosphatase activity and tumor suppressor gene [28]. PTEN could regulate tumor cell proliferation and apoptosis and also exerted a crucial role in tumor cell adhesion and metastasis[29]. Sui et al. reported that PCR and SSCP detection methods also found mutations and reduced protein expression of the PTEN gene in OC [30]. Schondorf et al. found that the PTEN gene had partial mutations or deletions in a variety of tumors and genetic diseases, and its mutation frequency is the highest in endometrioid adenocarcinoma [31]. In this study, our study demonstrated for the first time that pue evidently enhanced the P53, P21, and PTEN levels in a dosedependent manner. Moreover, pue mitigated the FGF1 level but slightly elevated the GLI2 level. The abovementioned events induced apoptosis and reduced the viability of OC cells.

In addition, to further check the related molecular mechanisms of pue-induced OC cell apoptosis and inhibition of proliferation, we tested the ERK1/2/NF-KB pathway. ERK, including ERK1 and ERK2, is key for extracellular signal transmission to the nucleus [32]. It has been manifested that activated ERK1/2 may cause cytoplasmic NF-kB to enter the nucleus and result in the activation of NF-KB [33]. NF-kBp65 and IkBa proteins are common members of the NF-KB family. NF-KB family proteins are one of the most studied nuclear transcription factors in recent years, which may be closely associated with the proliferation and apoptosis of tumor cells[34]. In our research, we discovered for the first time that pue greatly weakened the ratios of p-NF-KBp65/NF-KBp65, p-lkBa/lkBa, and p-ERK1/2/ERK1/2 in a dosedependent manner, indicating that pue restrained the growth of EC cells via repressing the ERK1/2-NF-KB axis.

In short, pue alleviated the malignant progression of OC cells by modulating p53 and PTEN expressions. In the future, we will conduct animal experiments to further verify the results in vivo.

\section{Declarations}

\section{Acknowledgement}

None.

\section{Conflict of interests}

The author declare that they have no competing interests. 


\section{Funding}

This work was supported by the Zhejiang Provincial Basic Public Welfare Research Plan Project (No. LGF20H270010).

\section{Author Contribution}

1)Protocol/project development Fu-le He

2) Data collection or management Yong-ju Ye

3) Data analysis Mei-lan Hu

4)Manuscript writing/editing Tian-yin Ruan

5) Obtaining funding Fu-le He

6)Revision of manuscript for important intellectual content Jiao-yi Pan

\section{References}

1. Siegel RL, Miller KD, Jemal A. Cancer statistics, 2019. CA: a cancer journal for clinicians. 2019;69(1):7-34.

2. La Vecchia C. Ovarian cancer: epidemiology and risk factors. European journal of cancer prevention : the official journal of the European Cancer Prevention Organisation (ECP). 2017;26(1):55-62.

3. Xu L, Deng Q, Pan Y, Peng M, Wang X, Song L, et al. Cancer-associated fibroblasts enhance the migration ability of ovarian cancer cells by increasing EZH2 expression. International journal of molecular medicine. 2014;33(1):91-6.

4. Holmes D. Ovarian cancer: beyond resistance. Nature. 2015;527(7579):S217.

5. Muramatsu M, Inoue S. Estrogen receptors: how do they control reproductive and nonreproductive functions? Biochemical and biophysical research communications. 2000;270(1):1-10.

6. Baird DD, Umbach DM, Lansdell L, Hughes CL, Setchell KD, Weinberg CR, et al. Dietary intervention study to assess estrogenicity of dietary soy among postmenopausal women. The Journal of clinical endocrinology and metabolism. 1995;80(5):1685-90.

7. Ingram D, Sanders K, Kolybaba M, Lopez D. Case-control study of phyto-oestrogens and breast cancer. Lancet (London, England). 1997;350(9083):990-4.

8. Birt DF, Hendrich S, Wang W. Dietary agents in cancer prevention: flavonoids and isoflavonoids. Pharmacology \& therapeutics. 2001;90(2-3):157-77.

9. Glazier MG, Bowman MA. A review of the evidence for the use of phytoestrogens as a replacement for traditional estrogen replacement therapy. Archives of internal medicine. 2001;161(9):1161-72. 
10. Constantinou A, Huberman E. Genistein as an inducer of tumor cell differentiation: possible mechanisms of action. Proceedings of the Society for Experimental Biology and Medicine Society for Experimental Biology and Medicine (New York, NY). 1995;208(1):109-15.

11. Wei SY. [Progress on cardiovascular protections and mechanism research of puerarin]. Zhongguo Zhong yao za zhi = Zhongguo zhongyao zazhi = China journal of Chinese materia medica. 2015;40(12):2278-84.

12. Wang T, Liu Y, Huang C, Mansai HAA, Wei W, Zhang X, et al. Puerarin promotes MIN6 cell survival by reducing cellular reactive oxygen species. Molecular medicine reports. 2018;17(5):7281-6.

13. Hu Y, Li X, Lin L, Liang S, Yan J. Puerarin inhibits non-small cell lung cancer cell growth via the induction of apoptosis. Oncology reports. 2018;39(4):1731-8.

14. Ullah MZ, Khan AU, Afridi R, Rasheed H, Khalid S, Naveed M, et al. Attenuation of inflammatory pain by puerarin in animal model of inflammation through inhibition of pro-inflammatory mediators. International immunopharmacology. 2018;61:306-16.

15. Chen X, Yu J, Shi J. Management of Diabetes Mellitus with Puerarin, a Natural Isoflavone From Pueraria lobata. The American journal of Chinese medicine. 2018;46(8):1771-89.

16. Jaroenporn S, Malaivijitnond S, Wattanasirmkit K, Trisomboon H, Watanabe G, Taya K, et al. Effects of Pueraria mirifica, an herb containing phytoestrogens, on reproductive organs and fertility of adult male mice. Endocrine. 2006;30(1):93-101.

17. Cheng W, Chen L, Yang S, Han J, Zhai D, Ni J, et al. Puerarin suppresses proliferation of endometriotic stromal cells partly via the MAPK signaling pathway induced by 17 ß-estradiol-BSA. PloS one. 2012;7(9):e45529.

18. Newman DJ, Cragg GM. Natural products as sources of new drugs over the 30 years from 1981 to 2010. Journal of natural products. 2012;75(3):311-35.

19. Koehn FE, Carter GT. The evolving role of natural products in drug discovery. Nature reviews Drug discovery. 2005;4(3):206-20.

20. Yu Z, Li W. Induction of apoptosis by puerarin in colon cancer HT-29 cells. Cancer letters. 2006;238(1):53-60.

21. Yang JA, Li JQ, Shao LM, Yang Q, Liu BH, Wu TF, et al. Puerarin inhibits proliferation and induces apoptosis in human glioblastoma cell lines. International journal of clinical and experimental medicine. 2015;8(6):10132-42.

22. Ye G, Kan S, Chen J, Lu X. Puerarin in inducing apoptosis of bladder cancer cells through inhibiting SIRT1/p53 pathway. Oncology letters. 2019;17(1):195-200.

23. Hwang LA, Phang BH, Liew OW, lqbal J, Koh XH, Koh XY, et al. Monoclonal Antibodies against Specific p53 Hotspot Mutants as Potential Tools for Precision Medicine. Cell reports. 2018;22(1):299312.

24. Gomes AS, Ramos H, Soares J, Saraiva L. p53 and glucose metabolism: an orchestra to be directed in cancer therapy. Pharmacological research. 2018;131:75-86. 
25. Vogelstein B, Lane D, Levine AJ. Surfing the p53 network. Nature. 2000;408(6810):307-10.

26. Klattenhoff CA, Scheuermann JC, Surface LE, Bradley RK, Fields PA, Steinhauser ML, et al. Braveheart, a long noncoding RNA required for cardiovascular lineage commitment. Cell. 2013;152(3):570-83.

27. Ahearn TU, Pettersson A, Ebot EM, Gerke T, Graff RE, Morais CL, et al. A Prospective Investigation of PTEN Loss and ERG Expression in Lethal Prostate Cancer. Journal of the National Cancer Institute. 2016;108(2).

28. Lynch ED, Ostermeyer EA, Lee MK, Arena JF, Ji H, Dann J, et al. Inherited mutations in PTEN that are associated with breast cancer, cowden disease, and juvenile polyposis. American journal of human genetics. 1997;61(6):1254-60.

29. Li J, Jiang K, Zhao F. Icariin regulates the proliferation and apoptosis of human ovarian cancer cells through microRNA-21 by targeting PTEN, RECK and Bcl-2. Oncology reports. 2015;33(6):2829-36.

30. Sui L, Dong Y, Watanabe Y, Yamaguchi F, Sugimoto K, Tokuda M. Alteration and clinical relevance of PTEN expression and its correlation with survivin expression in epithelial ovarian tumors. Oncology reports. 2006;15(4):773-8.

31. Schöndorf T, Ebert MP, Hoffmann J, Becker M, Moser N, Pur S, et al. Hypermethylation of the PTEN gene in ovarian cancer cell lines. Cancer letters. 2004;207(2):215-20.

32. Berti DA, Seger R. The Nuclear Translocation of ERK. Methods in molecular biology (Clifton, NJ). 2017;1487:175-94.

33. Lai JL, Liu YH, Liu C, Qi MP, Liu RN, Zhu XF, et al. Indirubin Inhibits LPS-Induced Inflammation via TLR4 Abrogation Mediated by the NF-kB and MAPK Signaling Pathways. Inflammation. 2017;40(1):1-12.

34. Han L, Zhang Y, Meng M, Cheng D, Wang C. Eicosapentaenoic acid induced SKOV-3 cell apoptosis through ERK1/2-mTOR-NF-KB pathways. Anti-cancer drugs. 2016;27(7):635-42.

\section{Figures}




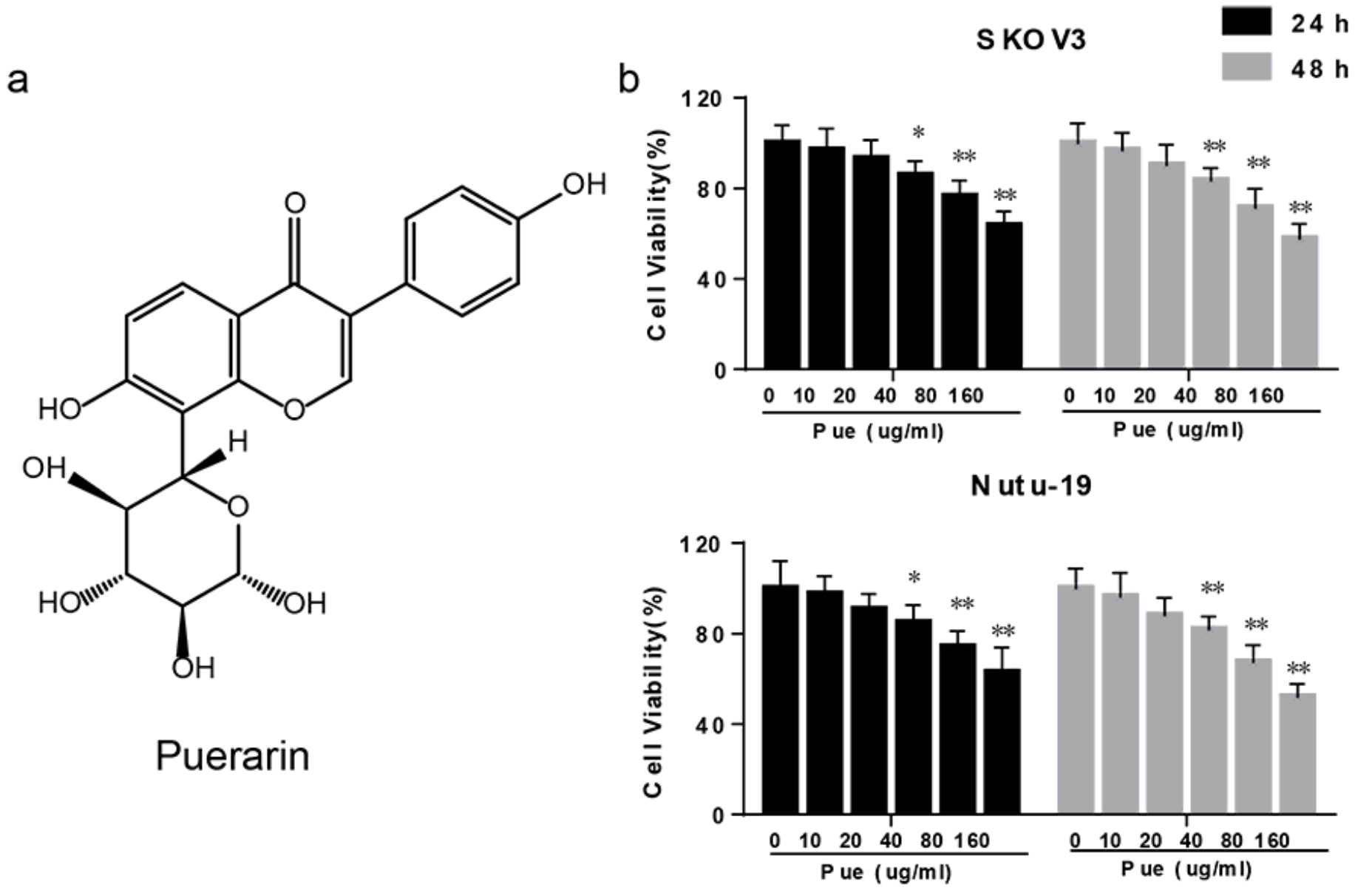

Figure 1

Pue weakened the OC cell vitality in a dose-dependent manner a. The chemical structure of puerarin (pue) was displayed in Figure 1a. b. The effect of different concentrations' pue on the cell vitality of SKOV3 and Nutu-19 cells was examined by cell counting kit (CCK-8). ${ }^{*} P<0.05,{ }^{*} \mathrm{P}<0.01$ vs. 0 group. Pue concentrations: $10,20,40,80$, and $160 \mu \mathrm{g} / \mathrm{mL}$. Pue: puerarin.

Pue $0 \mathrm{ug} / \mathrm{ml}$ Pue $40 \mathrm{ug} / \mathrm{ml}$ Pue $80 \mathrm{ug} / \mathrm{ml}$ Pue $160 \mathrm{ug} / \mathrm{ml}$

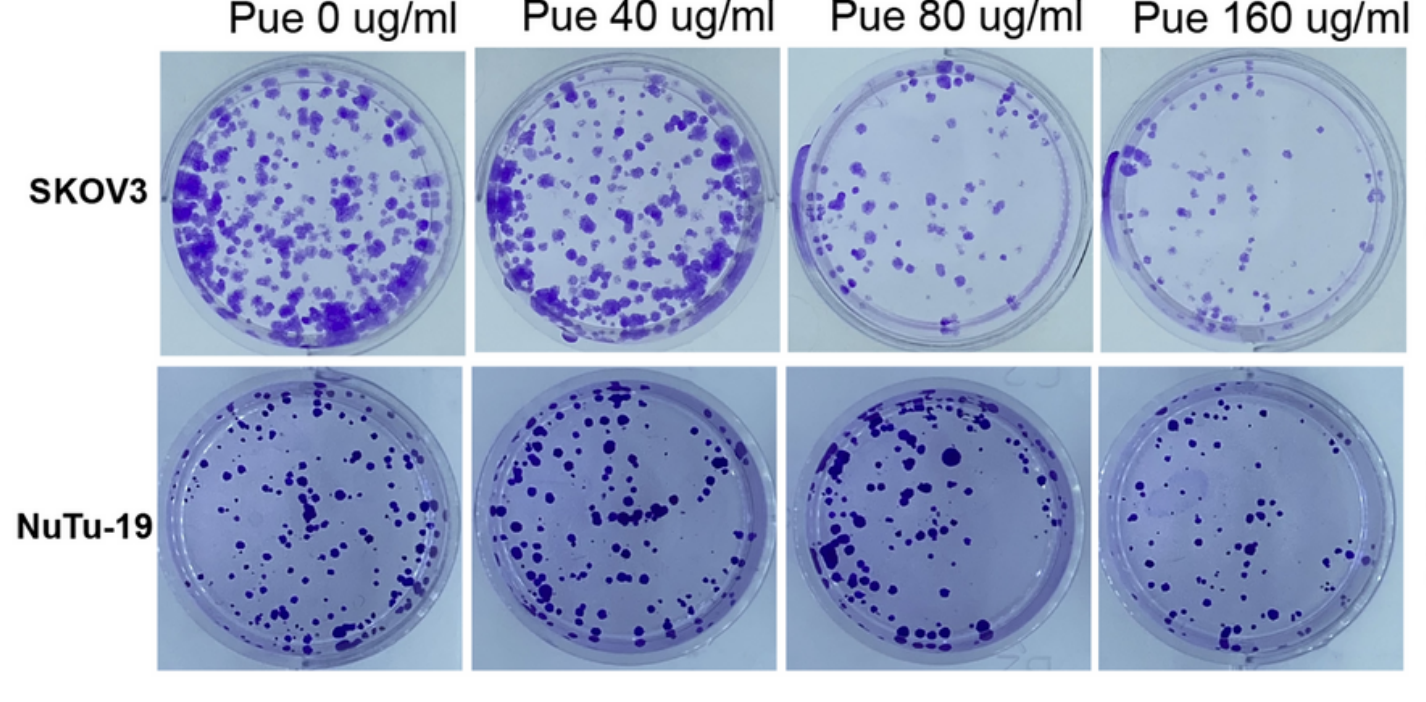

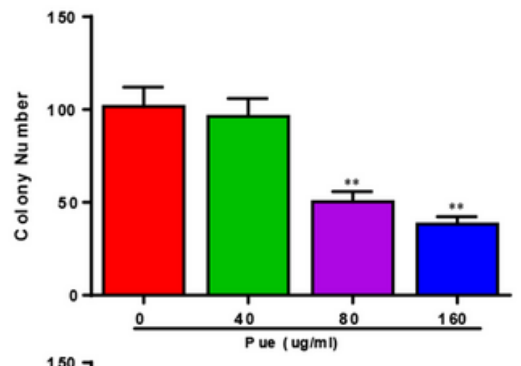

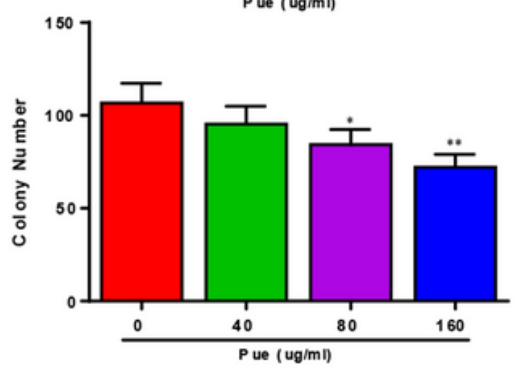

Figure 2 
Pue weakened the colony number of $\mathrm{OC}$ cells in a dose-dependent manner The effect of different concentrations' pue on the colony number of SKOV3 and Nutu-19 cells was examined by cell colonyforming experiment. ${ }^{*} \mathrm{P}<0.05$, ${ }^{\star *} \mathrm{P}<0.01$ vs. 0 group. Pue concentrations: 40,80 , and $160 \mu \mathrm{g} / \mathrm{mL}$. Pue: puerarin.

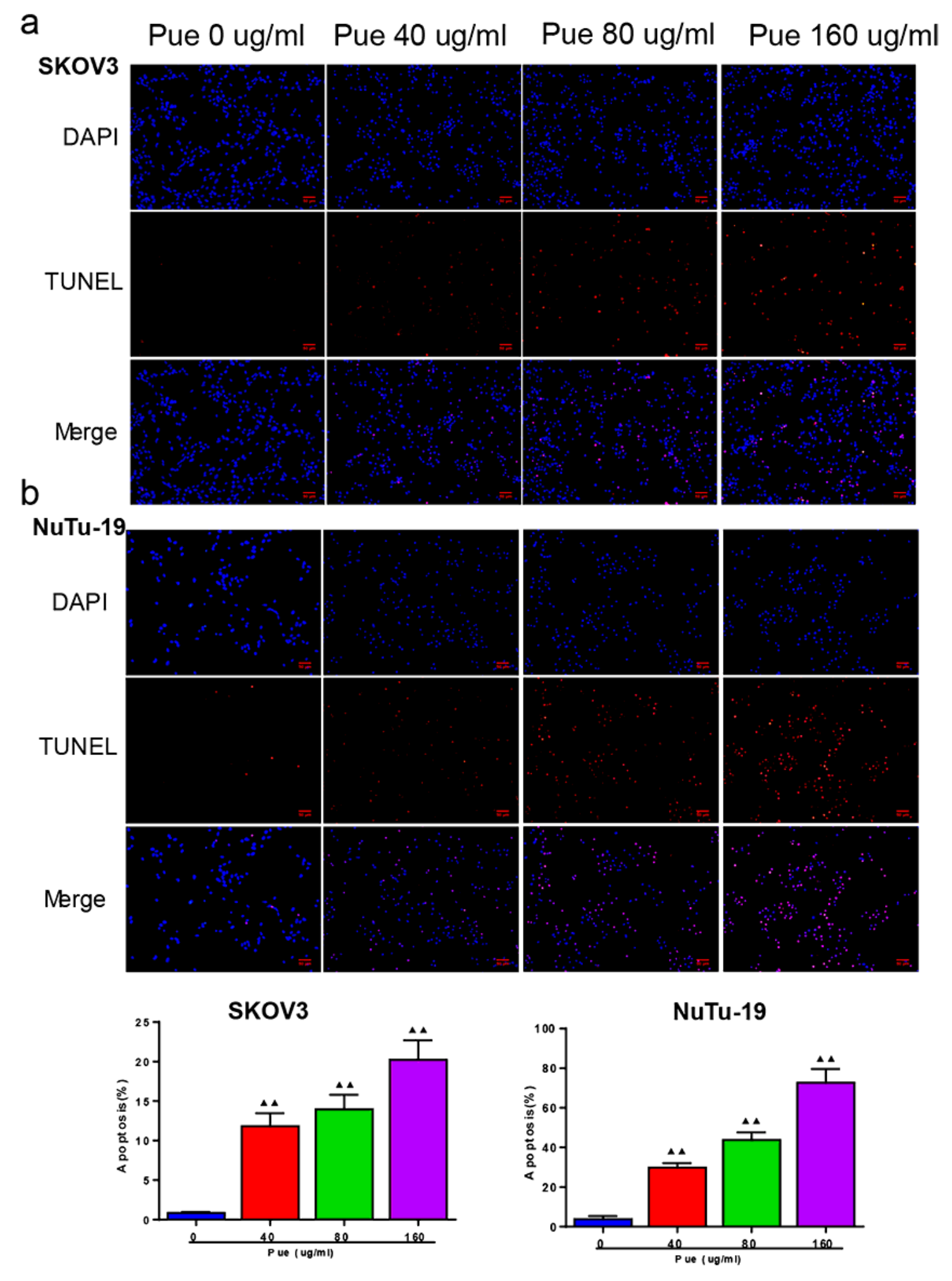

Figure 3 
Pue enhanced apoptosis of OC cells a-b. The effect of different concentrations' pue on apoptosis of SKOV3 and Nutu- 19 cells was examined by TUNEL staining. $\boldsymbol{\Delta} \mathbf{\Delta} P<0.05$ vs. 0 group. Pue concentrations: 40, 80, and $160 \mu \mathrm{g} / \mathrm{mL}$. Pue: puerarin.

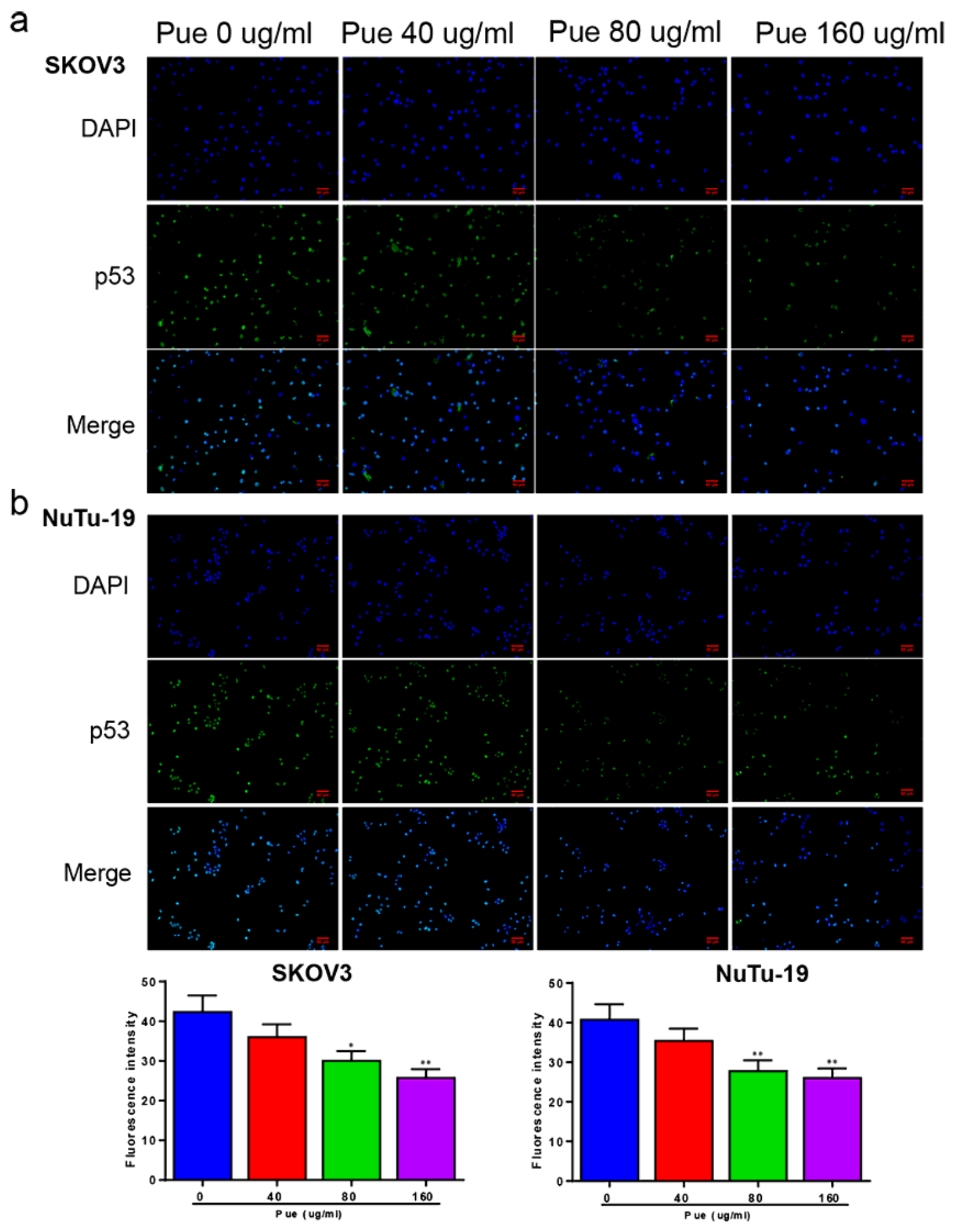

Figure 4

Pue blunted the positive expression of p53 in OC cells a-b. The effect of different concentrations' pue on the positive expression of p53 in SKOV3 and Nutu-19 cells was examined by immunofluorescence. 
${ }^{*} \mathrm{P}<0.05,{ }^{*} \mathrm{P}<0.01$ vs. 0 group. Pue concentrations: 40, 80, and $160 \mu \mathrm{g} / \mathrm{mL}$. Pue: puerarin.
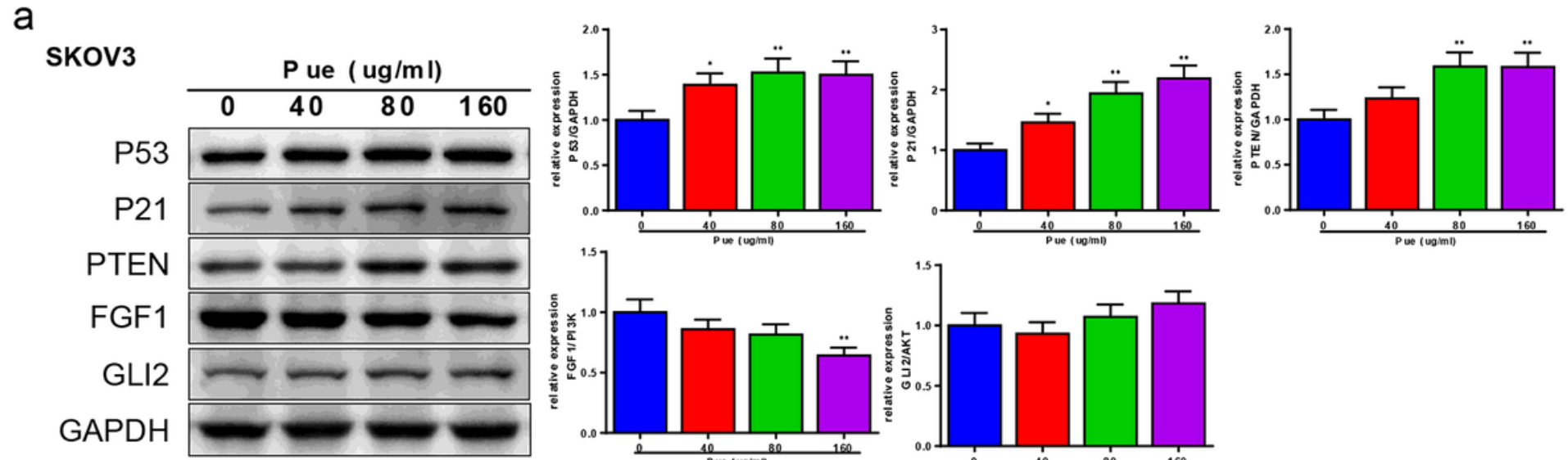

b
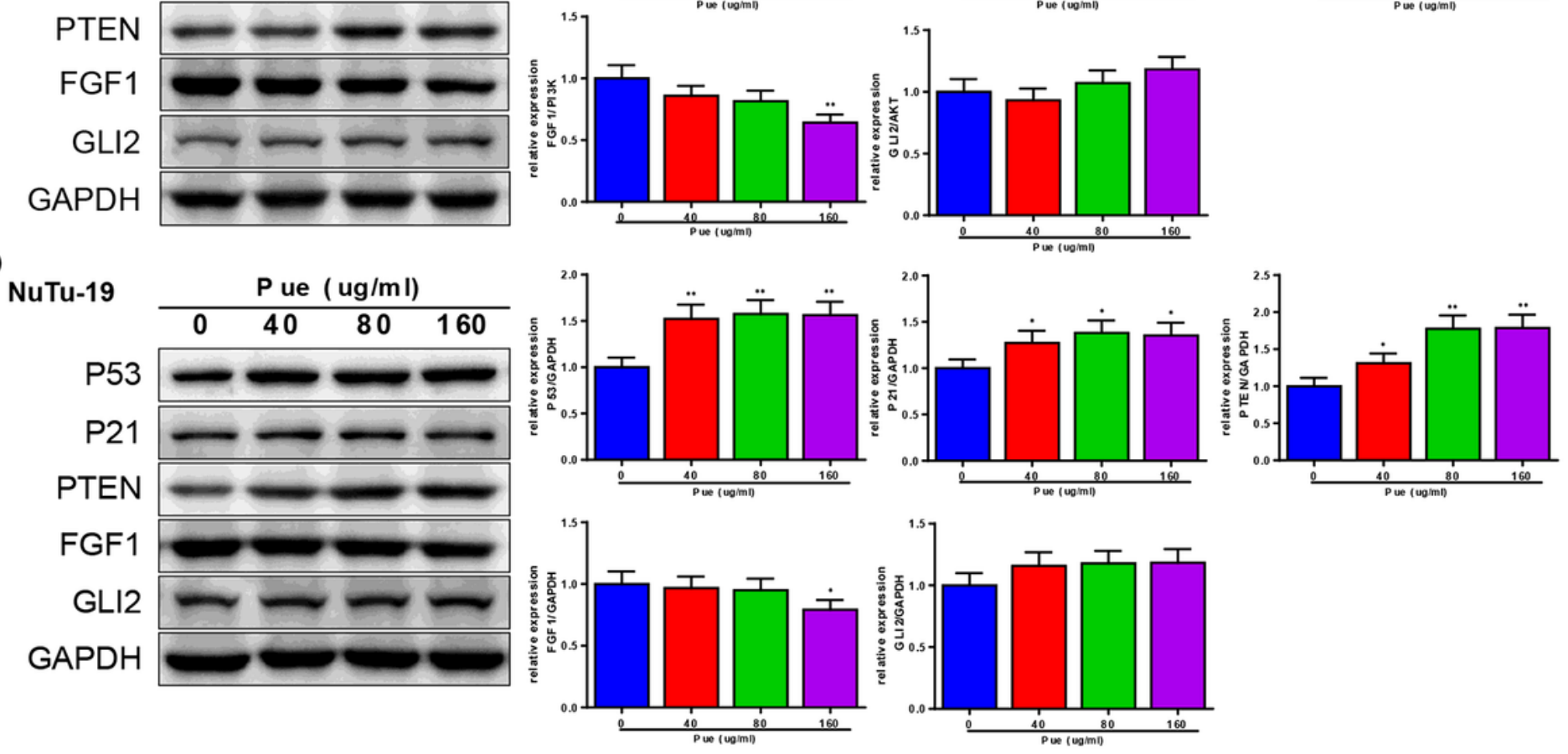

\section{Figure 5}

Pue enhanced the P53, P21, PTEN, and GLI2 levels but restrained the FGF1 level a-b. The effect of different concentrations' pue on the P53, P21, PTEN, FGF1, and GLI2 levels was examined by western blot. We used GAPDH as the internal control. ${ }^{*} P<0.05,{ }^{\star} * \mathrm{P}<0.01$ vs. 0 group. Pue concentrations: 40,80 , and $160 \mu \mathrm{g} / \mathrm{mL}$. Pue: puerarin. 


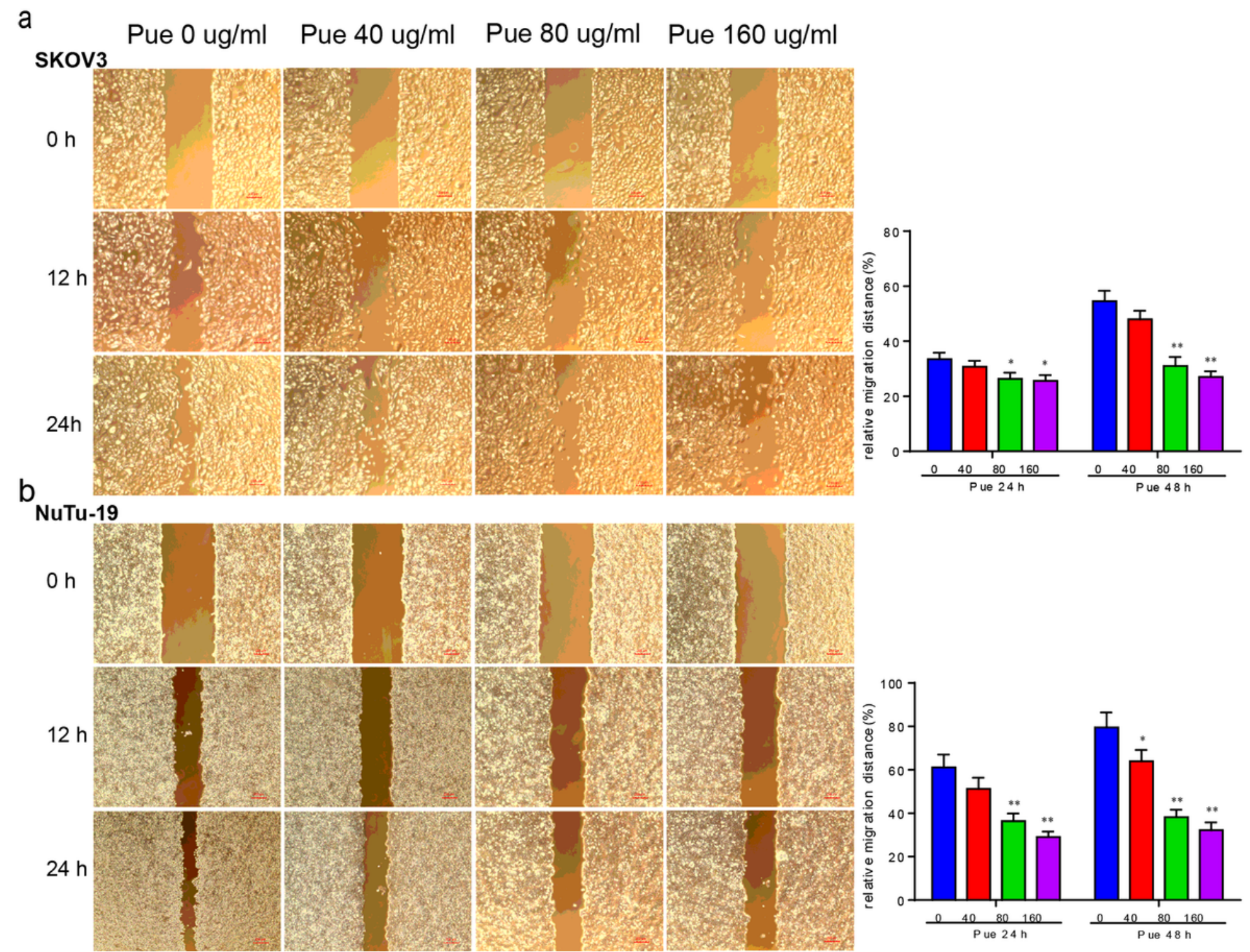

Figure 6

Pue alleviated the migration of OC cells $a-b$. The effect of different concentrations' pue on the migration of SKOV3 and Nutu-19 cells was examined by wound healing assay. ${ }^{*} P<0.05,{ }^{*} P<0.01$ vs. 0 group. Pue concentrations: 40,80 , and $160 \mu \mathrm{g} / \mathrm{mL}$. Pue: puerarin. 
a

SKOV3

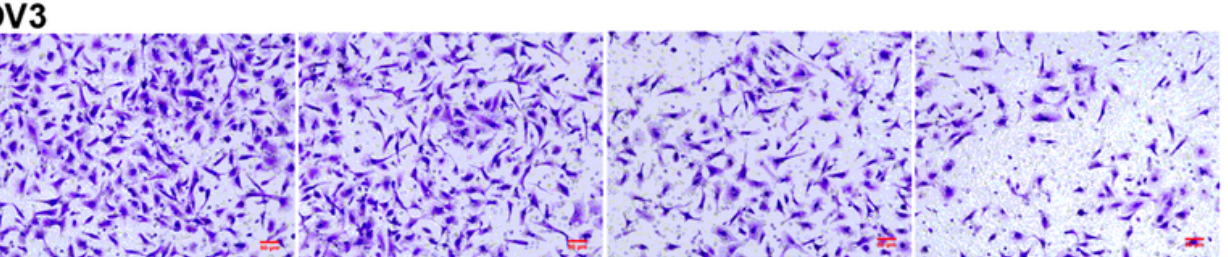

NuTu-19

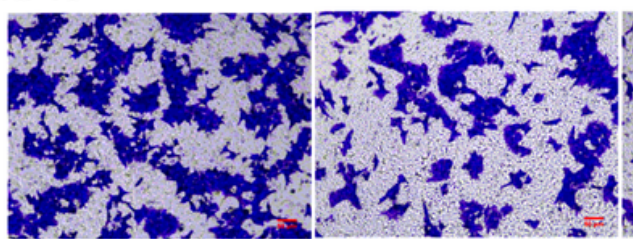

Pue 0 ug/ml Pue 40 ug/ml

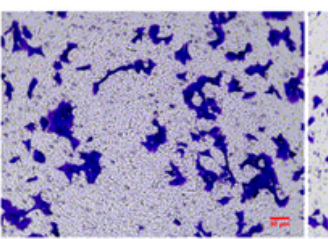

Pue $80 \mathrm{ug} / \mathrm{ml}$

b

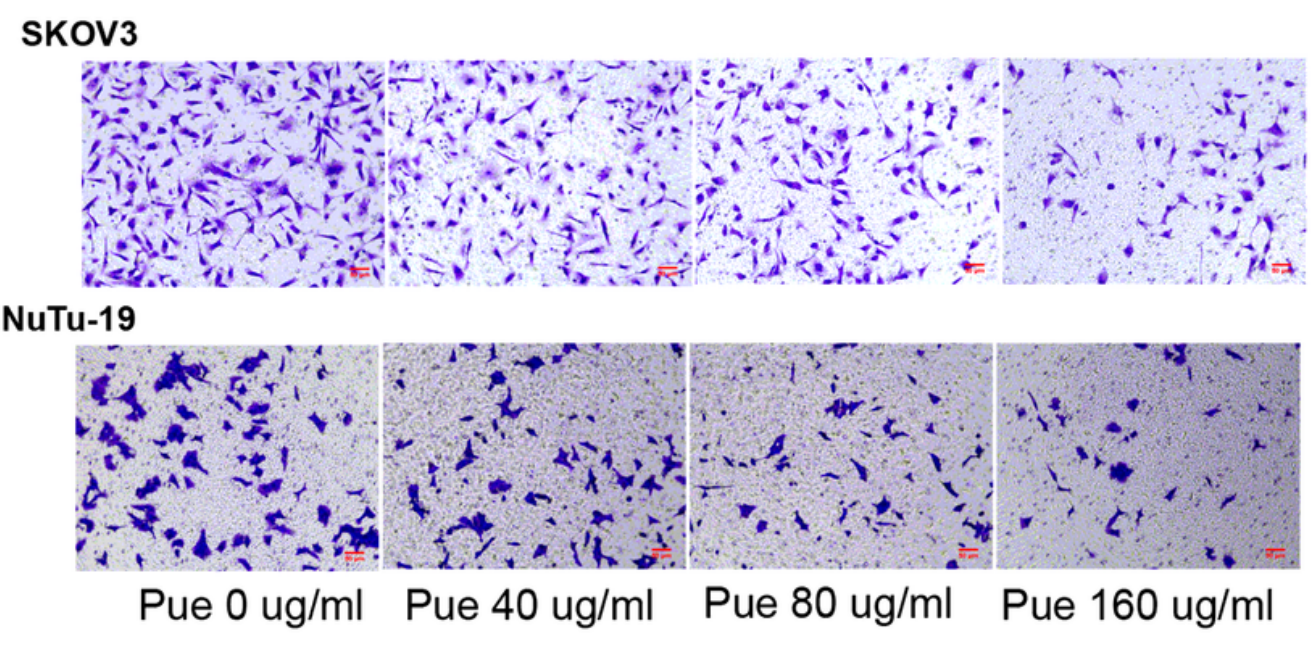

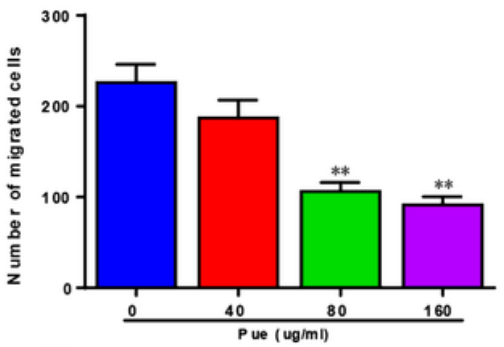
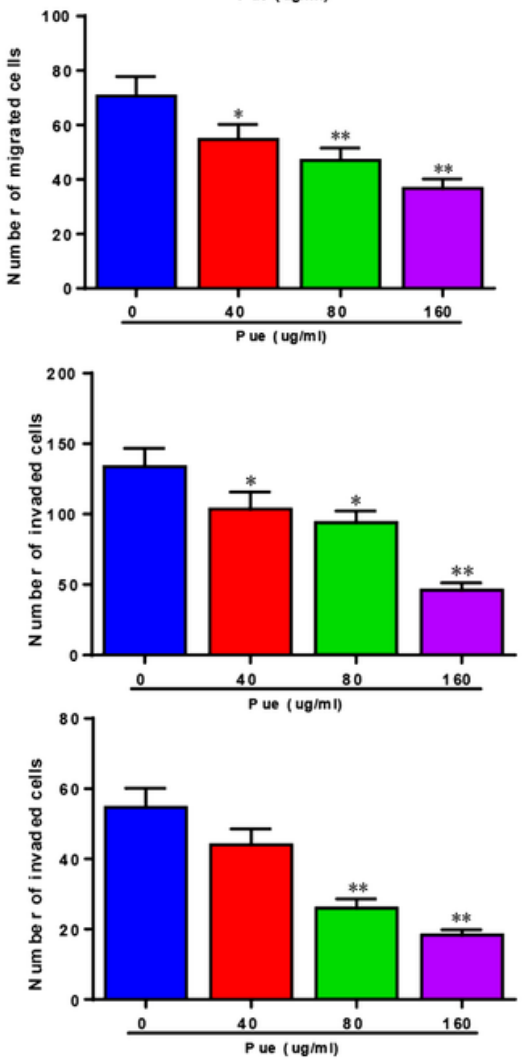

Figure 7

Pue alleviated the migration and invasion of $\mathrm{OC}$ cells $a-b$. The effect of different concentrations' pue on the migration and invasion of SKOV3 and Nutu-19 cells was examined by Transwell assay. ${ }^{*} P<0.05$, ${ }^{\star} * \mathrm{P}<0.01$ vs. 0 group. Pue concentrations: 40,80 , and $160 \mu \mathrm{g} / \mathrm{mL}$. Pue: puerarin. 

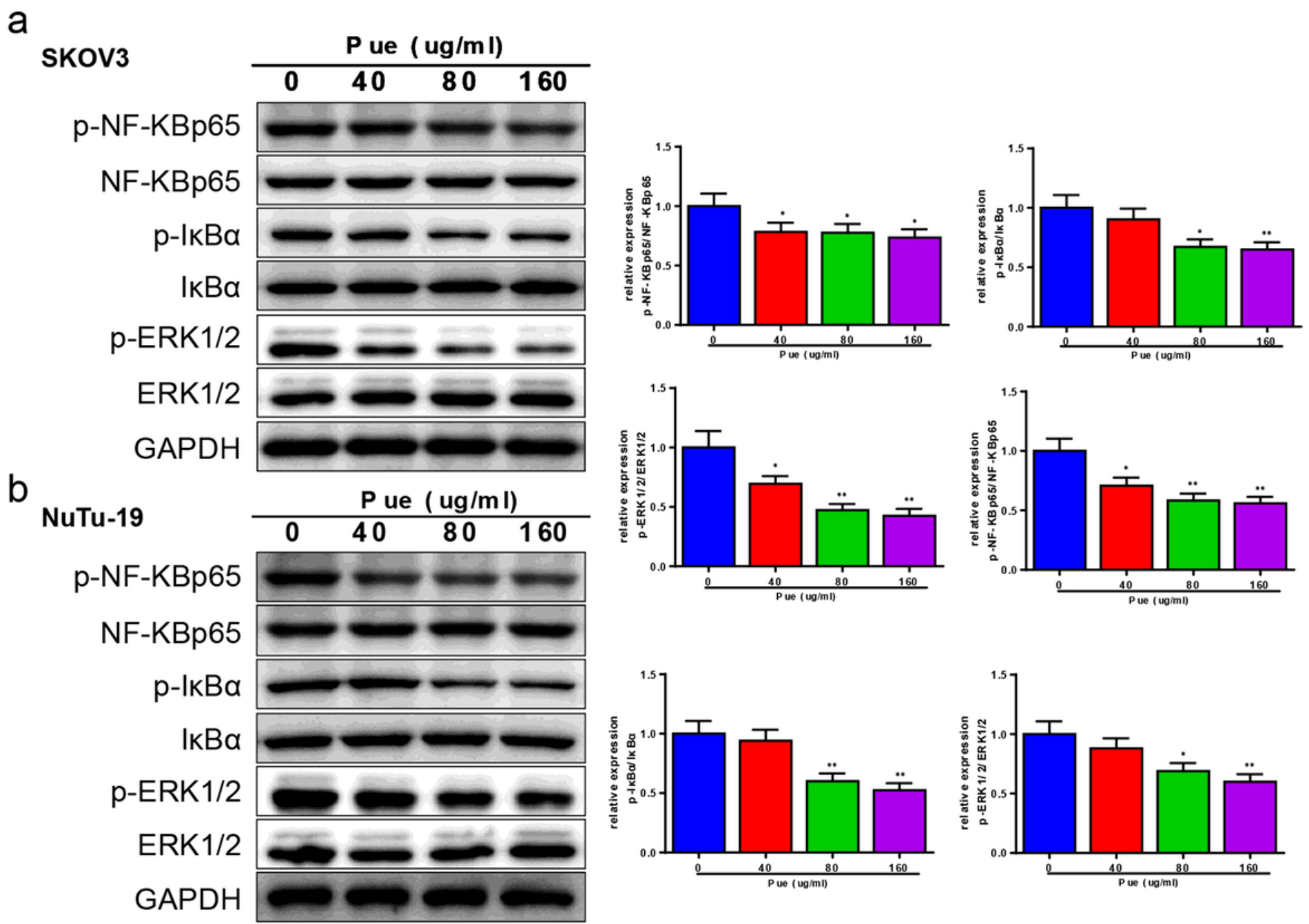

Figure 8

Pue weakened the ERK1/2-NF-KB pathway-related marker expressions a-b. The effect of different concentrations' pue on the ERK1/2-NF-KB pathway-related marker expressions was examined by western blot. We used GAPDH as the internal control. ${ }^{\star} P<0.05,{ }^{\star} * \mathrm{P}<0.01$ vs. 0 group. Pue concentrations: 40,80 , and $160 \mu \mathrm{g} / \mathrm{mL}$. Pue: puerarin. 